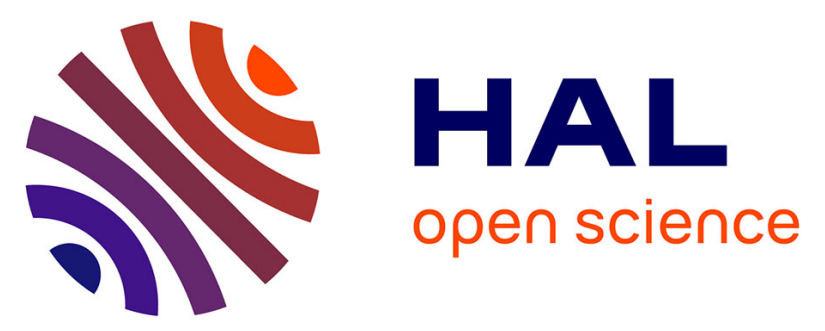

\title{
Characterization of intra-cellular ionic concentrations of monocytes in contact with bioactive glasses and hydroxyapatite particles. A TEM cryo-Xray analysis of diffusible ions
}

\author{
Edouard Jallot, P. Laquerriere, A. Grandjean-Laquerriere, L. Kilian, D. \\ Laurent-Maquin
}

\section{To cite this version:}

Edouard Jallot, P. Laquerriere, A. Grandjean-Laquerriere, L. Kilian, D. Laurent-Maquin. Characterization of intra-cellular ionic concentrations of monocytes in contact with bioactive glasses and hydroxyapatite particles. A TEM cryo-Xray analysis of diffusible ions. International Symposium on Trace Elements in Human: New Perspectives 4, Oct 2003, Athenes, Greece. pp.1303-1311. in2p300014096

\author{
HAL Id: in2p3-00014096 \\ https://hal.in2p3.fr/in2p3-00014096
}

Submitted on 3 Nov 2003

HAL is a multi-disciplinary open access archive for the deposit and dissemination of scientific research documents, whether they are published or not. The documents may come from teaching and research institutions in France or abroad, or from public or private research centers.
L'archive ouverte pluridisciplinaire HAL, est destinée au dépôt et à la diffusion de documents scientifiques de niveau recherche, publiés ou non, émanant des établissements d'enseignement et de recherche français ou étrangers, des laboratoires publics ou privés. 
Characterization of intra-cellular ionic concentrations of monocytes in contact with bioactive glasses and hydroxyapatite particles. A TEM cryo-Xray analysis of diffusible ions.

E. JALLOT ${ }^{1 *}$, P. LAQUERRIERE ${ }^{2}$, A. GRANDJEAN- LAQUERRIERE ${ }^{3}$, L. KILIAN², D. LAURENT-MAQUIN ${ }^{2}$

${ }^{1}$ Laboratoire de Physique Corpusculaire de Clermont-Ferrand CNRS/IN2P3 UMR 6533, 24 avenue des Landais, 63177 AUBIERE Cedex, France

2 INSERM ERM 0203, Laboratoire de Microscopie Electronique, 21 rue Clément Ader, 51685 REIMS Cedex 2, France

${ }^{3}$ Laboratoire d'Immunologie et de Biotechnologies, UFR Pharmacie, EA2070, IFR 53, 1 avenue du maréchal Juin, 51100 Reims, France

* Corresponding author :

Edouard JALLOT

Laboratoire de Physique Corpusculaire de Clermont-Ferrand CNRS/IN2P3 UMR 6533

Université Blaise Pascal - 24 avenue des Landais, 63177 Aubiere Cedex, France.

Tel : $33(0) 473407265$

Fax : $33(0) 473264598$

E-mail : jallot@clermont.in2p3.fr 


\begin{abstract}
Cells viability can be altered by the presence of bioactive materials particles and their features. This paper compares the influence of hydroxyapatite particles and bioactive glass particles on intracellular ionic concentrations of the monocytes exposed to them. However, microanalysis of intracellular ions like sodium, potassium, chlorine is a major problem. In order to limit diffusion phenomenon and to preserve the chemical identity of specimens, we used cryomethods (cryo-preparation, cryo-Xray microanalysis) to study cells in contact with bioactive materials particles. We measured intracellular ionic concentrations by scanning transmission electron microscopy (STEM) associated to energy dispersive X-ray spectroscopy (EDXS). Monocytes were exposed to bioactive glass particles and to hydroxyapatite particles during two days. The K/Na ratio was used as a sensitive criteria of viability of cells. Bioactive glass particles and in a less manner hydroxyapatite particles have an effect on intracellular ionic concentrations. These two types of bioactive particles alter cells. However, bioactive glass particles appear to alter cells more than hydroxyapatite particles.
\end{abstract}

Keywords : bioactive glasses, hydroxyapatite, cytotoxicity, cryo-X-ray microanalysis, diffusible ions, $[\mathrm{K}] /[\mathrm{Na}]$ 


\section{Introduction}

Calcium phosphate ceramics (hydroxyapatite) and bioactive glasses are widely used as bone substitutes or to coat metal implants in order to improve their biocompatibility ${ }^{1,2}$. These materials are bioactive materials. They permit an intimate chemical bond with bone tissues through a biologically active apatite layer. This apatite is formed during the material dissolution and through physico-chemical reactions at the particles periphery. However, the dissolution of these materials can lead to the release of particles into the surrounding bone tissues ${ }^{3,4}$. After implantation, the first cells to colonize the biomaterials surface and the released particles are the monocytes and giant cells. They play a major role in the host defensive mechanism by their phagocytic capability ${ }^{5}$. Different authors demonstrated that cells viability can be altered by the presence of particles, ${ }^{6,7}$ Moreover, particles features (composition, size, surface area...) can influence cell activity ${ }^{7,8,9}$.

The aim of this paper is to compare the influence of two bioactive materials (hydroxyapatite, bioactive glass) on the survival of the monocytes that phagocytose them. In our study, hydroxyapatite $\left(\mathrm{Ca}_{10}\left(\mathrm{PO}_{4}\right)_{6}(\mathrm{OH})_{2}\right)$ particles size is between $150-300 \mu \mathrm{m}$ and is composed with crystals of the order of $350 \mathrm{~nm}$. Bioactive glass is amorphous and is in the $\mathrm{SiO}_{2}-\mathrm{Na}_{2} \mathrm{O}-\mathrm{CaO}-\mathrm{P}_{2} \mathrm{O}_{5}-\mathrm{K}_{2} \mathrm{O}-\mathrm{Al}_{2} \mathrm{O}_{3}-\mathrm{MgO}$ system. Bioactive glass particles size is between $100-$ $300 \mu \mathrm{m}$. In order to evaluate the influence of particles on intracellular ionic concentrations and their cytotoxicity on cells, we measure intracellular ionic concentrations by scanning transmission electron microscopy (STEM) associated to energy dispersive X-ray spectroscopy (EDXS).

But, microanalysis of diffusible ions like sodium, potassium, and chlorine is a major problem $^{10,11}$. These elements are not very firmly bound and they can be solubilized during specimen preparation. Thin biological samples for transmission electron microscopy are usually prepared by a process involving fixation, postfixation, dehydration, embedding in 
resin and sectioning. During this chemical fixation, most of the diffusible ions are rapidly lost (within minutes) from the samples ${ }^{11,12}$. In order to preserve the chemical identity of specimens we used cryomethods for the preparation of cells in contact with bioactive materials particles. These methods permit retention of all elements of interest at their in vitro location close to their native state and allow identification at the level of analytical resolution required. In this work, we paid particular attention to the potassium-sodium ratio which is one of the most sensitive criteria of viability ${ }^{13,14}$. This criteria has already been used to demonstrated cellular alterations induced by biomaterials such as zircon particles ${ }^{8}$, hydroxyapatite particles ${ }^{15}$ and bioactive glass particles ${ }^{16}$.

\section{Materials and Methods}

\section{Hydroxyapatite particles}

Powder was made of pure crystalline hydroxyapatite $\left(\mathrm{Ca}_{10}\left(\mathrm{PO}_{4}\right)_{6}(\mathrm{OH})_{2}\right)$ with a purity over 99\%. The HA particles had indifferent shapes with a distribution size between 150 and 300 $\mu \mathrm{m}$. They were sintered at $1180^{\circ} \mathrm{C}$ and their crystal size was around $350 \mathrm{~nm}$.

Bioactive glass particles

The bioactive glass composition is $50 \% \mathrm{SiO}_{2}, 20 \% \mathrm{Na}_{2} \mathrm{O}, 16 \% \mathrm{CaO}, 6 \% \mathrm{P}_{2} \mathrm{O}_{5}, 5 \% \mathrm{~K}_{2} \mathrm{O}, 2 \%$ $\mathrm{Al}_{2} \mathrm{O}_{3}$ and $1 \% \mathrm{MgO}$ (\% weight). The bioactive glass was obtained by melting the components in a platinum crucible at $1350^{\circ} \mathrm{C}$. After the melting process, the glass was cast, crushed, and ground into a powder with grain sizes between 100-300 $\mu \mathrm{m}$ in an alumina ball mill.

\section{Cell cultures}

Elutriated monocytes obtained from two healthy volunteer donors were used. They were maintained in RPMI-1640 medium (Gibco, France) supplemented with 10\% fetal calf serum (Gibco, France), 2mM glutamine, penicillin (5000 U.ml ${ }^{-1}$ ) and streptomycin (25 $\mu \mathrm{g} . \mathrm{ml}^{-1}$ ) 
(called standard medium) at $37^{\circ} \mathrm{C}$ in a saturated $5 \% \mathrm{CO}_{2}$ and $95 \%$ air atmosphere. The cell density was $2.10^{5}$ cells. $\mathrm{ml}^{-1}$ in a 5-ml total volume.

It has been shown that there is an effect of surface area of polymethylmethacrylate particles on monocytes activity ${ }^{17}$. The calculation of the surface area ratio (SAR= surface area of cell/surface area of material) demonstrated that cells were sensitive to the surface of material presents in the cell culture. Cellular activity was measured through a range of SAR from 0.1 to 10 . The activity increased from a minimum at an SAR of 10 and reached the maximum at an SAR of 1 . Below 1, the cellular activity was not affected by the SAR ${ }^{7}$. From all these data, we have chosen a surface area ratio equal to 1.

In this work, three experiments were conducted : the first was a control cells, performed with cells alone in a standard medium. The second experiment consisted of cells exposed to bioactive glass powders with a SAR equal to one. The third experiment consisted of cells exposed to hydroxyapatite powders with a SAR equal to one.

\section{Sample preparation for cryomicroanalysis}

After 2 days of culture, the medium of each experiment was removed by centrifugation. Droplets of cells deposited on aluminium specimen holders $(0.7 \mathrm{~mm}$ diameter made in our laboratory) were cryofixed by plunging into melting ethane cooled by liquid nitrogen $\left(-196^{\circ} \mathrm{C}\right)$ with a velocity of $2 \mathrm{~m} \cdot \mathrm{s}^{-1}$ using a home made cryoplunging system. The frozen specimens were stored in liquid nitrogen before cryosectionning.

Cryosections were cut with a Leica Ultracut E ultramicrotome equipped with an FC-4 cryosectionning attachment (Leica) using a $45^{\circ}$ dry glass knife. The specimen temperature was $-140^{\circ} \mathrm{C}$ and knife temperature was $-145^{\circ} \mathrm{C}$. The cutting speed was $0.5 \mathrm{~mm} . \mathrm{s}^{-1}$ and the microtome advance 70-90 nm per stoke, giving ultra-thin cryosections. Sections were 
deposited onto carbon coated collodion on 200-mesh copper grid, pressed onto the grid and stored in liquid nitrogen.

\section{Instrumentation and analytical conditions}

The grids bearing the cryosections were placed into a pre-cooled GATAN cryo-specimen holder and transferred into the microscope chamber. Sections were freeze-dried by warming up them slowly $\left(30 \mathrm{~min}\right.$ ) from $-196^{\circ} \mathrm{C}$ to $-70^{\circ} \mathrm{C}$. They were cooled to $-170^{\circ} \mathrm{C}$ for analysis. Analyses described in this paper were carried out using a Scanning Transmission Electron Microscope (STEM) (Philips CM 30). The vacuum in the column was maintained at $<2.10^{-7}$ Torr. The microscope is fitted with an EDAX $30 \mathrm{~mm}^{2} \mathrm{Si}(\mathrm{Li})$ R-SUTW detector (Mn K $\alpha$ resolution $140 \mathrm{eV}$, take-off angle $14.1^{\circ}, 0.15$ sr detection solid angle). Data was acquired with the specimen holder at a $30^{\circ}$-tilt and a microscope accelerating voltage of $100 \mathrm{kV}$. Beam current was constant at $0.07 \mathrm{nA}$. The elemental composition of dry specimens was determined by using the normalized Hall continuum method ${ }^{18-19}$ and are expressed in mmol.kg ${ }^{-1}$ dry weight. Mean values of elemental concentrations were obtained by scanning the electron probe over a $4 \mu \mathrm{m}^{2}$ sample area during $200 \mathrm{~s}$ (which correspond to $2410^{3} \mathrm{e}^{-} . \mathrm{nm}^{-2}$ ).

In each experiment, ionic concentrations of at least 15 cells from each donor were evaluated. All elemental concentrations and potassium to sodium ratios shown are the means of all data determined in each cell. Statistical significance between results obtained on cells exposed to bioactive glass particles or to hydroxyapatite particles and the control cells was determined by using the Mann-Witney U-test (error probability p; * : p<0.05). 


\section{Results}

Figures 1 represents the elemental concentrations in the cytoplasm of the control cells, of cells exposed to bioactive glass particles and cells exposed to hydroxyapatite particles.

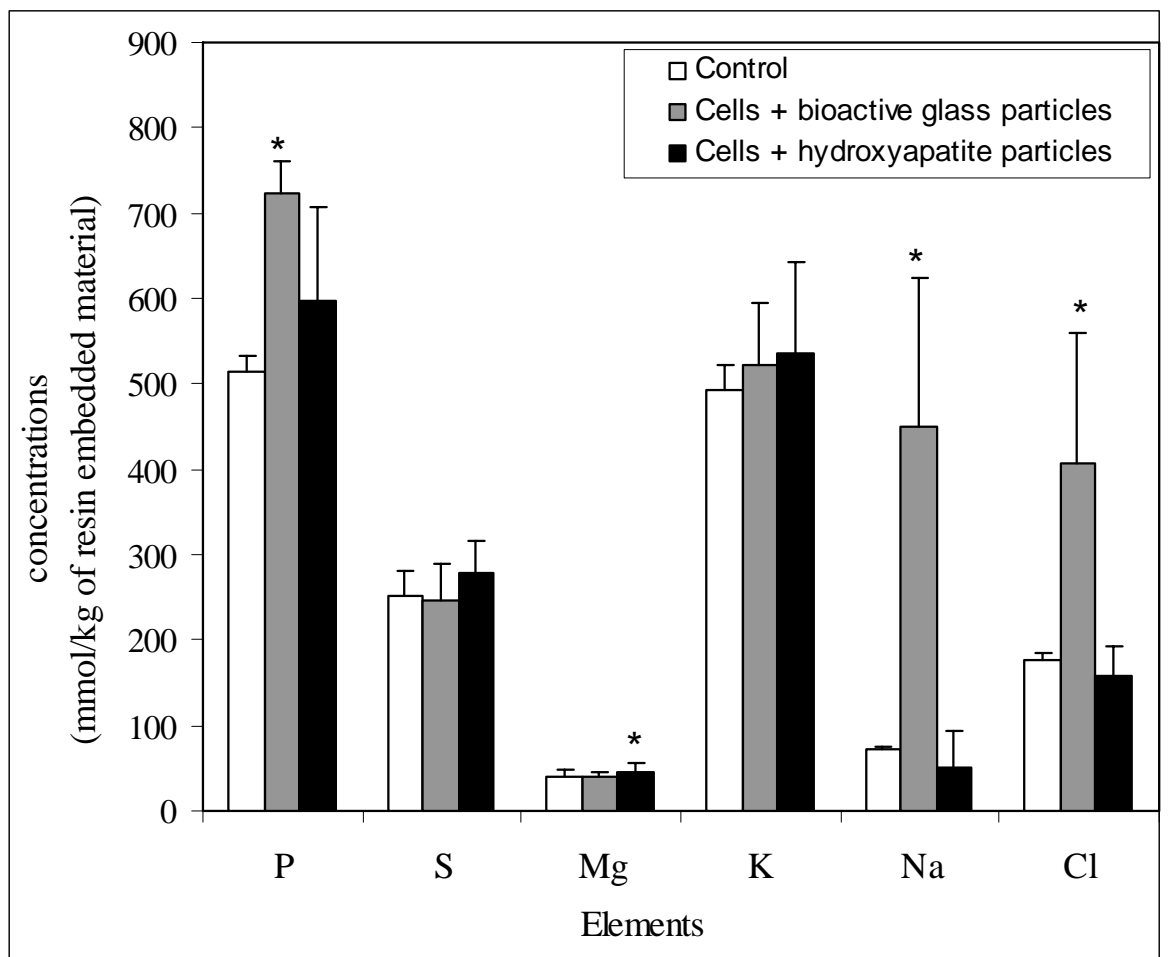

Figure 1 : Cytoplasmic P, S, Mg, K, Na, Cl concentrations in control cells, in cells exposed to bioactive glass particles and in cells exposed to hydroxyapatite particles.

The results show a high increase of phosphorus, sodium and chlorine concentrations when cells are cultured with bioactive glass particles (figure 1). On the other hand, sulphur, potassium and magnesium concentrations are quite the same in the control cells and in cells exposed to bioactive glass particles. Phosphorus, sulphur, potassium, sodium and chlorine stay constant when cells are exposed to hydroxyapatite particles. A slight increase in magnesium concentration is observed. 


\section{K/Na ratio}

The higher K/Na ratio was measured in the control cells and the lower was obtained in cells exposed to bioactive glass particles (Table 1). The $\mathrm{K} / \mathrm{Na}$ ratio in cells cultured with hydroxyapatite particles was intermediary.

\begin{tabular}{cc}
\hline & K/Na \\
\hline Control & $7.59 \pm 0.31$ \\
Cells + bioactive glass particles & $3.51 \pm 3.19$ \\
Cells + hydroxyapatite particles & $5.16 \pm 0.90$ \\
\hline
\end{tabular}

Table 1 : Mean value of the potassium:sodium ratio in control cells, in cells exposed to bioactive glass particles and in cells exposed to hydroxyapatite particles.

\section{Discussion}

In this paper, we have studied intracellular concentrations of cells after exposure to bioactive glass particles or to hydroxyapatite particles. In order to avoid ions diffusions, conventional fixation method for TEM analysis are not the best choice. Study of intracellular concentrations requires cryotechniques for sample preparation and analysis. We were able to measure $\mathrm{P}, \mathrm{S}, \mathrm{Mg}, \mathrm{K}, \mathrm{Na}$ and $\mathrm{Cl}$ concentrations in cellular compartments. The high standard deviations obtained in the experiments represent inhomogeneities in the cellular populations.

When cells were exposed to bioactive glass, there was a significant increase in phosphorus. Phosphorus reflects the phosphorylation state. This increase of $\mathrm{P}$ concentration can signify a phosphorylation state higher than in control cells. 
For diffusible ions, fluctuation of potassium, sodium and chlorine concentration might be a consequence of damage to cell membranes because according to the electrochemical gradient, $\mathrm{Na}$ and $\mathrm{Cl}$ might have been allowed to penetrate into the cell. It seemed to be the case with bioactive glass particles because an increase of $\mathrm{Na}$ and $\mathrm{Cl}$ is observed. Since generally membrane potential is given by intracellular and extracellular concentrations of $\mathrm{Na}$, $\mathrm{Cl}$ and $\mathrm{K}$, modifications in the concentrations of these elements inside the cell cytoplasm raise the possibility of changes in membrane potential. It has been suggested that depolarization could be the result of an increase in the permeability of the plasma membrane of epithelial cells to ions ${ }^{20}$, and that fluctuation of membrane fluidity induces modification of membrane permeability to water, ions and solutes ${ }^{21}$.

On the other hand, hydroxyapatite particles induced an increase in intracellular magnesium concentration that might be related to an increase in ATP concentration because $\mathrm{Mg}$ is known to be bond to $\mathrm{ATP}^{22}$. Moreover, magnesium is an important regulator of mitochondrial functions ${ }^{23}$, where the ATP formation takes place.

The K/Na ratio permits the evaluation of the toxic effects of bioactive glass particles and hydroxyapatite particles. Our results demonstrated that the bioactive glass particles were more toxic for monocytes compared to hydroxyapatite particles.

\section{Conclusion}

In this paper, we study intracellular ionic concentrations in monocytes exposed to bioactive glass particles and to hydroxyapatite particles. Concentrations were determined by cryo-X-ray microanalysis associated to electron probe microscopy. These methods allow us to study diffusible ions and to obtain intracellular concentrations in cells close to the physiological state. Moreover, the $\mathrm{K} / \mathrm{Na}$ ratio was used as a sensitive criteria of viability of cells. 
Bioactive glass particles and in a less manner hydroxyapatite particles have an effect on intracellular ionic concentrations. These two types of bioactive particles alter cells. However, bioactive glass particles appear to alter cells more than hydroxyapatite particles. 


\section{References}

1. Hench L.L. Biomaterials : A forecast for the future. Biomaterials, 19, 1419-1423 (1998).

2. Jallot E., Benhayoune H., Kilian L., Irigaray J.L., Oudadesse H., Balossier G., Bonhomme P. STEM and EDXS characterisation of physico-chemical reactions at the interface between a bioglass coating and bone. Surface and Interface Analysis 29 (2000) 314.

3. Jallot E., Benhayoune H., Kilian L., Irigaray J.L., Barbotteau Y., Balossier G., Bonhomme P. Dissolution kinetics, selective leaching and interfacial reactions of a bioglass coating enriched in alumina. J. Colloid Interface Sc. 233 (2001) 83.

4. Benhayoune H., Jallot E., Laquerriere P., Balossier G., Bonhomme P., Frayssinet P. Integration of dense HA rods into cortical bone. Biomaterials 21 (2000) 235.

5. Heymann D., Pradal G., Benahmed M.. Cellular machanisms of calcium phosphate ceramic degradation. Histol. Histopathol. 14 (1999) 871.

6. Ross L. Benghuzzi H., Tucci M., Callender M., Cason Z., Spence L. The effect of HA, TCP and ALCAP bioceramic capsules on the viability of human monocytes and monocyte derived macrophages. Biomed. Sci. Instrum. 32 (1996) 71.

7. Shanbhag A.S., Jacobs J.J., Blacks J., Galante J.O., Glant T.T. Macrophage/particle interactions: effects of size, composition and surface area. J. Biomed. Mater. Res. 28 (1994) 81.

8. Nkamgueu E.M., Adnet J.J., Bernard J., Zierold K., Kilian L., Jallot E., Benhayoune H., Bonhomme P. In vitro effects of zirconia and alumina particles on human blood monocytesderived macrophages : X-ray microanalysis and flow cytometric studies. J. Biomed. Mater. Res. 52-4 (2000) 587.

9. Laquerriere P., Grandjean-Laquerriere A., Jallot E., Balossier G., Frayssinet P., Guenounou M. Importance of hydroxyapatite particles characteristics on cytokines production by human monocytes in vitro. Biomaterials 24-16 (2003) 2739 
10. Zierold K. Cryofixation methods for ion localization in cells by electron probe microanalysis. J. Microscopy 161 (1991) 357.

11. Jallot E., Benhayoune H., Kilian L., Josset Y., Balossier G. An original method to assess short-term physicochemical reactions at the periphery of bioactive glasse particles in biological fluids. Langmuir 17 (2001) 4467.

12. Roomans G.M. Quantitative X-ray microanalysis of biological specimens. J. Electron. Microsc. Tech. 9-1 (1988) 19.

13. Baur H., Kasperek S., Pfaff E. Criteria of viability of isolated cells. Hopp-Seyler Z Physiol Chem. 356 (1975) 827.

14. Zierold K. Effects of cadmium on electrolyte ions in cultured rat hepatocytes studied by X-ray microanalysis of cryosections. Toxicol Appl. Pharmacol. 144 (1997) 70.

15. Laquerriere P., Kilian L., Bouchot A., Jallot E., Grandjean A., Guenounou M., Balossier G., Frayssinet P., Bonhomme P. Effect of hydroxyapatite sintering temperature on intracellular ionic concentrations of monocytes : a TEM-cryo-X-ray microanalysis study. J. Biomed. Mater. Res. 58-3 (2001) 238.

16. Laquerriere P., Jallot E., Kilian L., Benhayoune H., Balossier G. Effects of bioactive glass particles and ionic products of bioactive glass particles on intracellular concentrations. J. Biomed. Mater. Res. 65A (2003) 441.

17. Gonzalez O., Smith R.L., Goodman S.B. Effect of size, concentration, surface area, and volume of polymethylmethacrylate particles on human macrophages in-vitro. J. Biomed. Mater. Res. 30 (1996) 463.

18. Laquerriere P., Banchet V., Michel J., Zierold K., Balossier G., Bonhomme P. X-ray microanalysis of organic thin sections in TEM using an UTW Si(Li) detector. Comparison of quantification methods. Microsc. Res. Tech. 52 (2001) 231. 
19. Hall T.A. Physical techniques in biological research, Vol. I Part A, $2^{\text {nd }}$ ed.; Oster, G., Ed.; Academic press: New York, 1971; Chapter. 3.

20. P. Rothenberg, L. Reuss, and L. Glaser, "Serum and epidermal growth factor transiently depolarize quiescent BSC-1 epithelial cells”, Proc Natl Acad Sci USA., 79, 7783-7787 (1982).

21. W.G. Hill, R.L. Rivers, and M.L. Zeidel, "Role of leaflet asymetry in the permeability of model biological membranes to protons, solutes and gases”, J. Gen. Physiol., 114, 405-414 (1999).

22. Grubbs R., Maguire M. Magnesium as a regulatory cation : criteria and evaluation. Magnesium 6 (1987) 113.

23. Di Francesco A., Desnoyer R.W., Covacci V., Wolf F.I., Romani A., Cittadini A., Bond M. Changes in magnesium content and subcellular distribution during acid-induced differentiation of HL60 cells. Archives of Biochemistry and Biophysics. 360 (1998) 149. 